\title{
Endemic HTLV in Japan and South America with special reference to mongoloid dispersal from Asia to the Andes
}

\author{
Kazuo Tajima ${ }^{1}$, Shunro Sonoda ${ }^{2}$, Luis Cartier ${ }^{3}$, Vladimir Zaninovic ${ }^{4}$, Lautaro NúÑez ${ }^{5}$, Luis Hurtado ${ }^{6}$, Sonia

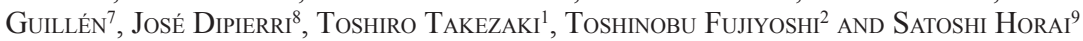

\section{RESUMEN}

Se ha estimado que existe 1,2 millones de portadores del virus humano de la leucemia T tipo I (HTLV I) en todo el Japón, donde la incidencia de leucemia a linfocitos T del adulto es la más alta del mundo.

Si se compara la distribución geográfica del HTLV-I y HTLV-II entre los portadores del virus en Sudamérica, se observa que el primero (HTLV-I) está limitado al área andina y que de norte a sur incluye: Colombia, Ecuador, Perú, Bolivia, Chile y Argentina. Mientras que el segundo (HTLV-II), se expande entre el resto de los nativos sudamericanos desde el borde del Caribe al extremo sur de la Patagonia.

El origen tanto del HTLV-I como HTLV-II en estas regiones no ha sido completamente aclarado, pero muy probablemente se liga a la historia de la dispersión humana en este continente, donde en algún momento se crearon grupos con una exclusiva localización geográfica que transmitieron el virus de

1 Division of Epidemiology, Aichi Cancer Center Research Institute, Kanokoden 1-1, Chikusa-ku, Nagoya 464-8681, JAPAN.

2 Department of Virology, Kagoshima University, Sakuragaoka 8-35-1, Kagoshima 890-8520, JAPAN.

3 Department of Clinical Neurology, Chile University, Santiago, CHILE.

4 Departmentofclinical Neurology, Valle University, Cali, COLOMBIA.

5 Institute of Archaeology, Research and Museum, North Catholic University, San Pedro de Atacama, CHILE.

6 Bolivia Science Academy, La Paz, BOLIVIA.

7 Centro Malqui Museum, llo, PERU.

8 Department of Medical Anthropology, Jujuy University, Jujuy, ARGENTINA.

9 The Graduate University for Advanced Studies, Hayama, Japan. madres a hijos y de hombre a mujer bajo condiciones naturales.

Para explicar esta transposición única del HTLV-I desde los asiáticos del Japón a los andinos de Sudamérica se han desarrollado diferentes modelos hipotéticos de esta histórica migración de los portadores de HTLV-I y HTLV-II.

La similitud en el antecedente genético que muestran los japoneses del sur y los pueblos andinos de Sudamérica sugiere una hipótesis migratoria plausible, pero que no encuentra general aceptación entre antropólogos y arqueólogos. Suponemos que los portadores de HTLV-I llegaron a América del Sur y a los Andes a través de una ruta transpacífica, mucho después que los portadores de HTLV-II venidos de Asia arribaran al continente Sudamericano.

\section{Introduction}

The human T-cell lymphotropic virus (HTLV) is classified into two types, HTLV-I(Poiesz et al., 1980; Hinuma et al., 1981) and HTLV-II (Kalyanaraman et al., 1982). HTLV-I is the main causal agent of adult T-cell leukemia/lymphoma (ATL) (Uchiyama (et al., 1977) and HTLV-I associated myelopathy/ tropical spastic paraparesis (HAM/TSP) (Osame et al., 1986; Gessain et al., 1985), found throughout the world, whereas HTLV-II is only detected in very limited groups in America and Africa. Phylogenetically, three subtypes of HTLV-I, groups of viral strains with common nucleotides in any provirus portion of their DNA sequences, have been assigned as the names cosmopolitan, central African and Melanesian (Koralnik et al., 1994; Ido et al., 1996).

Based on strict confirmatory studies of HTLV-I antibodies, endemic groups, defined by high HTLV-I prevalence rates, include certain Mongoloids in Asia and South America, Negroids in tropical Africa, the Caribbean as well as the Atlantic coast of South America, and Australoids in Papua New Guinea and north Australia (Tajima and Hinuma, 1992). 
The distributions of HTLV-I and -II foci showed a characteristic geographical independence, HTLV-I foci for example being present in the Andes highlands and HTLV-II foci in Pan American lowlands in South America.

The geographical distribution of HTLV-I is considered important evidence of the migration history of our ancestors from anthropological and ethnological points of view. The unique ethnic clusters of patients with HTLV-I associated diseases in the world can be explained by the natural history of familial transmission of HTLV-I which is limited to mother-to-child (breast feeding) and man-to-woman (sexual contact) (Tajima, 1996). The present study reviews the geographical distribution of HTLV-I in the Pan Pacific region and the prehistoric dispersal of paleo-Mongoloids from Asia to the American continent.

\section{EPIDEMIOLOGICAL FEATURES OF HTLV-I}

South America: HTLV-I positive cases were found in indigenous groups in the Andes highlands, while HTLV-II positive cases were broadly detected in lowland ethnic groups (Table 1). Incidence rates of HTLV-I and HTLV-II carriers varied with each ethnic group, ranging from $0.8 \%$ to $27.3 \%$ for HTLV-I seropositivity and $1.4 \%$ to $57.9 \%$ for HTLVII seropositivity. Relatively high incidence of HTLVI infection were found in Colombian Kamsa (6.8\%), Paez (6.3\%) and Inga (2.1\%), Peruvian Aymara (1.6\%), Bolivian Aymara (6.0\%) and Quechua (4.5\%), Argentine Puna (2.3\%), and Chilean Atacama (5.6\%). Major HTLV-II foci were identified in Colombian Guahibo (31.5\%) and Wayu (4.1\%), Brazilian Kayapo (57.9\%), Paraguayan Chaco (16.4\%), and Chilean Alacalufes (34.8\%) and Yaganes (9.1\%). In addition, Black populations on the Pacific coast of Colombia demonstrated a high level HTLV-I seropositives (6.3\%) (Figure 1).

Asia: In the far east Asian countries other than Japan, only a hunting-gathering people, the Aeta in the Philippines, have a conspicuously high rate of HTLV-I carriers (Ishida et al., 1988). A recent study showed more than $10 \%$ of the Mashadi Jews in northern Iran to carry the virus (Meytes et al., 1990). In other central Asian countries, sporadic distributions of HTLV-I carriers and patients with ATL were disclosed recently among Chinese on the east coast of China, Singapore, and Hong Kong,
Koreans in Korea, Indians in Singapore and India, Jewish in Israel and Eskimos in Alaska (Tajima and Hinuma, 1992). We found no evidence of any HTLVII clustering area and/or ethnic groups in Asian countries.

Japan: According to evidence obtained from a biennial nationwide surveillance of ATL carried out in Japan since 1986, the annual incidence is estimated to be 700 within approximately 1.2 million HTLV-I carriers in Japan (Tajima et al., 1990). The affected individuals mainly inhabit the southern and northern ATL endemic areas (Table 2 and Fig. 2). Among 2,264 ATL patients newly diagnosed during the 6 years from 1990 to 1995 (The T- and B-cell Malignancy Study Group, 1998), 71\% were born in the Southwestern districts of Kyushu and Shikoku, and $8.4 \%$ in the northern districts of Hokkaido and Tohoku.

\section{TRANSMISSION ROUTES OF HTLV-I}

Mother-to-child transmission: The primary route appears to be transmission from a mother with HTLV-I antigen-positive lymphocytes in her breast milk to her child (Tajima et al., 1982; Kinoshita et al., 1984). This vertical transmission occurs until approximately 1-2 years of age and infection remains stable until young adulthood. Only very rarely antibody expression after transmission of HTLV-I delayed for as long as several decades (Kusuhara et al., 1990) and, it has been suggested that seroconversion after vertical transmission of HTLV-I normally occurs during the first 2-3 years. The overall infection rate from carrier mothers to their children (younger than 19 years) has been estimated to be $10-30 \%$ in Japan (Tajima and Hinuma, 1992).

Sexual transmission: The second important route of natural transmission is horizontal transmission between men and women. A study of married couples strongly suggests that HTLV-I is transmitted mainly from husband to wife (Tajima et al., 1982). Between the two partners in a marriage, the limited conditions checked suggest that the infected $\mathrm{T}$ cells of the carrier enter the non-carrier's body, so that transmission from wife to husband does not easily occur. Detection of HTLV-I in semen from carrier males supports the possibility of the oneway transmission from males to females via semen (Nakano et al., 1984). One possible explanation for the universal increasing trend with age in carrier 


\begin{tabular}{|c|c|c|c|c|c|c|c|c|}
\hline \multirow[t]{2}{*}{ Country } & \multirow[t]{2}{*}{ Ethnicity } & \multirow[t]{2}{*}{ Locality (Area) } & \multirow{2}{*}{$\begin{array}{l}\text { Date(Mo/Yr) } \\
\text { of sampling }\end{array}$} & \multirow{2}{*}{$\begin{array}{l}\text { Number } \\
\text { of subjects }\end{array}$} & \multirow{2}{*}{$\begin{array}{l}\text { Age } \\
\text { (years) }\end{array}$} & \multicolumn{2}{|c|}{ Number of seropositives } & \multirow{2}{*}{$\frac{\mathrm{M} / \mathrm{F} \#}{\text { Ratio }}$} \\
\hline & & & & & & HTLV-I(\%) & HTLV-II(\%) & \\
\hline \multirow[t]{11}{*}{ Colombia } & Paez* 1 & Paez (Andes) & $08 / 1989$ & 32 & $18-53$ & $2(6.3 \%)$ & 0 & $5 / 27$ \\
\hline & Guambiano*1 & Silvia (Andes) & 08/1989 & 53 & $18-53$ & 0 & 0 & $20 / 33$ \\
\hline & Inga*4 & Aponte (Andes) & $08 / 1990$ & 48 & $15-65$ & $1(2.1 \%)$ & 0 & $15 / 33$ \\
\hline & Kamsa*2 & Sibundoy (Andes) & 08/1991 & 59 & $11-71$ & $4(6.8 \%)$ & 0 & $7 / 52$ \\
\hline & Cumbal*4 & Cumbal (Andes) & 08/1991 & 55 & $16-60$ & 0 & 0 & $14 / 41$ \\
\hline & Guahibo*4 & Puerto Carreno (Orinoco) & $08 / 1992$ & 92 & $10-65$ & 0 & $29(31.5 \%)$ & $44 / 48$ \\
\hline & Wayu*4 & Guajira (Atlantic Coast) & 08/1991 & 123 & $8-80$ & 0 & $5(4.1 \%)$ & $46 / 77$ \\
\hline & \multicolumn{8}{|c|}{$\& 08 / 1992$} \\
\hline & Amazonas*1 & Leticia \& Narino (Amazon) & $11 / 1989$ & 85 & $13-79$ & 0 & 0 & $33 / 52$ \\
\hline & Amazonas & Leticia \& La Pedrera (Amazon) & 08/1990 & 80 & $14-62$ & 0 & 0 & $39 / 41$ \\
\hline & Black & Guapi \& Timbiqui (Pacific Coast) & $08 / 1990$ & 270 & $14-80$ & $17(6.3 \%)$ & 0 & $90 / 180$ \\
\hline \multirow[t]{3}{*}{ Venezuela } & Yanomami & Majawana et al (Gyana) & $10 / 1993$ & 129 & $10-60$ & 0 & 0 & $74 / 55$ \\
\hline & Ye’kuana & Chajorana (Orinoco) & $10 / 1993$ & 40 & $10-60$ & 0 & 0 & $12 / 28$ \\
\hline & Piaroa & Manapiare (Orinoco) & $10 / 1993$ & 30 & $14-60$ & 0 & 0 & $13 / 17$ \\
\hline Brazil & Kayapo & Xingu (Amazonas) & $09 / 1990$ & 19 & $8-74$ & 0 & $11(57.9 \%)$ & NS\# \\
\hline \multirow[t]{2}{*}{ Peru } & Aymara & Carumas (Andes) & 08/1997 & 28 & $19-74$ & $1(3.6 \%)$ & 0 & $15 / 13$ \\
\hline & Aymara & San Cristóbal et al (Andes) & 08/1997 & 34 & $18-56$ & 0 & 0 & $16 / 18$ \\
\hline \multirow[t]{13}{*}{ Bolivia } & Aymara & Huachacalla (Andes) & 08/1996 & 32 & $28-78$ & $6(18.8 \%)$ & 0 & $18 / 14$ \\
\hline & \multicolumn{8}{|c|}{$\&$ 08/1997 } \\
\hline & Aymara & Escara (Andes) & 08/1996 & 7 & $48-77$ & $(1(14 \%)$ & 0 & $6 / 1$ \\
\hline & Aymara & Achacachi (Andes) & $08 / 1995$ & 49 & $13-75$ & 0 & 0 & $17 / 32$ \\
\hline & Aymara & Sabaya \& et al (Andes) & $08 / 1997$ & 12 & $35-90$ & 0 & 0 & $4 / 8$ \\
\hline & Aymara & Llica (Andes) & $08 / 1997$ & 51 & 6-78 & $2(4.0 \%)$ & 0 & $23 / 28$ \\
\hline & Quechua & San Juan (Andes) & $08 / 1997$ & 26 & $12-76$ & $3(11.5 \%)$ & 0 & $9 / 17$ \\
\hline & Quechua & Copacabana (Andes) & 08/1997 & 20 & $12-77$ & 0 & 0 & $8 / 12$ \\
\hline & Quechua & Alota (Andes) & $08 / 1997$ & 29 & $17-74$ & 0 & 0 & $8 / 21$ \\
\hline & Quechua & Quelena Chico (Andes) & $08 / 1998$ & 10 & $30-80$ & 0 & 0 & $4 / 6$ \\
\hline & Quechua & San Pablo de Lipez (Andes) & $08 / 1998$ & 11 & $32-65$ & $3(27.3 \%)$ & 0 & $4 / 87$ \\
\hline & Quechua & Candelaria (Andes valley) & $08 / 1995$ & 38 & $14-80$ & 0 & 0 & $14 / 24$ \\
\hline & Chipaya & Chipaya (Andes) & 08/1999 & 9 & $20-60$ & 0 & 0 & $6 / 3$ \\
\hline \multirow[t]{2}{*}{ Argentina } & Puna & Susques (Andes) & $06 / 1997$ & 40 & $18 / 56$ & $1(2.5 \%)$ & 0 & $19 / 21$ \\
\hline & Puna & Cochinoca (Andes) & $10 / 1997$ & 48 & $16-88$ & $1(2.1 \%)$ & 0 & $13 / 35$ \\
\hline Paraguay & Chaco & Colonias Mennonilas (Chaco) & 03/1998 & 146 & $14-75$ & 0 & $24(16.4 \%)$ & $71 / 75$ \\
\hline \multirow[t]{10}{*}{ Chile } & Aymara*5 & Putre et al (Andes) & $12 / 1992$ & 57 & $18-82$ & 0 & 0 & $24 / 33$ \\
\hline & Atacama*5 & Toconao (Andes) & $11 / 1992$ & 29 & $19-78$ & $4(13.8 \%)$ & 0 & $10 / 19$ \\
\hline & Atacama*5 & San Pedro (Andes) & $11 / 1992$ & 44 & $19-89$ & $5(11.4 \%)$ & 0 & $13 / 31$ \\
\hline & Atacama*5 & Caspana et al (Andes) & $11 / 1992$ & 87 & $17-89$ & 0 & 0 & $30 / 57$ \\
\hline & Mapuche*3 & Los Galpones et al (Andes plain) & $01 / 1991$ & 133 & $12-81$ & $1(0.8 \%)$ & 0 & $54 / 79$ \\
\hline & Pehuenche*3 & Icalma(Andes) & $01 / 1991$ & 10 & $18-63$ & 0 & 0 & $3 / 7$ \\
\hline & Hulliches*3 & Chiloe Island (Pacific coast) & $01 / 1991$ & 70 & $13-83$ & $1(1.4 \%)$ & $1(1.4 \%)$ & $29 / 41$ \\
\hline & Alacalufes*5 & Wellington Island (Pacific coast) & $11 / 1993$ & 23 & $14-73$ & 0 & $8(34.8 \%)$ & $9 / 14$ \\
\hline & Yaganes*5 & Navarino Island (Patagonia) & $12 / 1993$ & 22 & $13-70$ & 0 & $2(9.1 \%)$ & $9 / 13$ \\
\hline & Rapa Nui & Easler Island (Pacific ocean) & 09/1996 & 132 & $7-86$ & $1(0.8 \%)$ & 0 & $44 / 88$ \\
\hline
\end{tabular}

* 1 Data reported by Zamora el al. (4)

* 2 Data reported by Fujiyama el al. (13)

* 3 Data reported by Cartier el al. (16)

* 4 Data reported by Zaninovic el al. (17)

* 5 Data reported in part by Tajima el al. (18)

\# Male/Female ratios (NS: M/F was not specified)

Table 1. Summary Results of Serological Tests for HTLV-I/II in South American Native Groups 


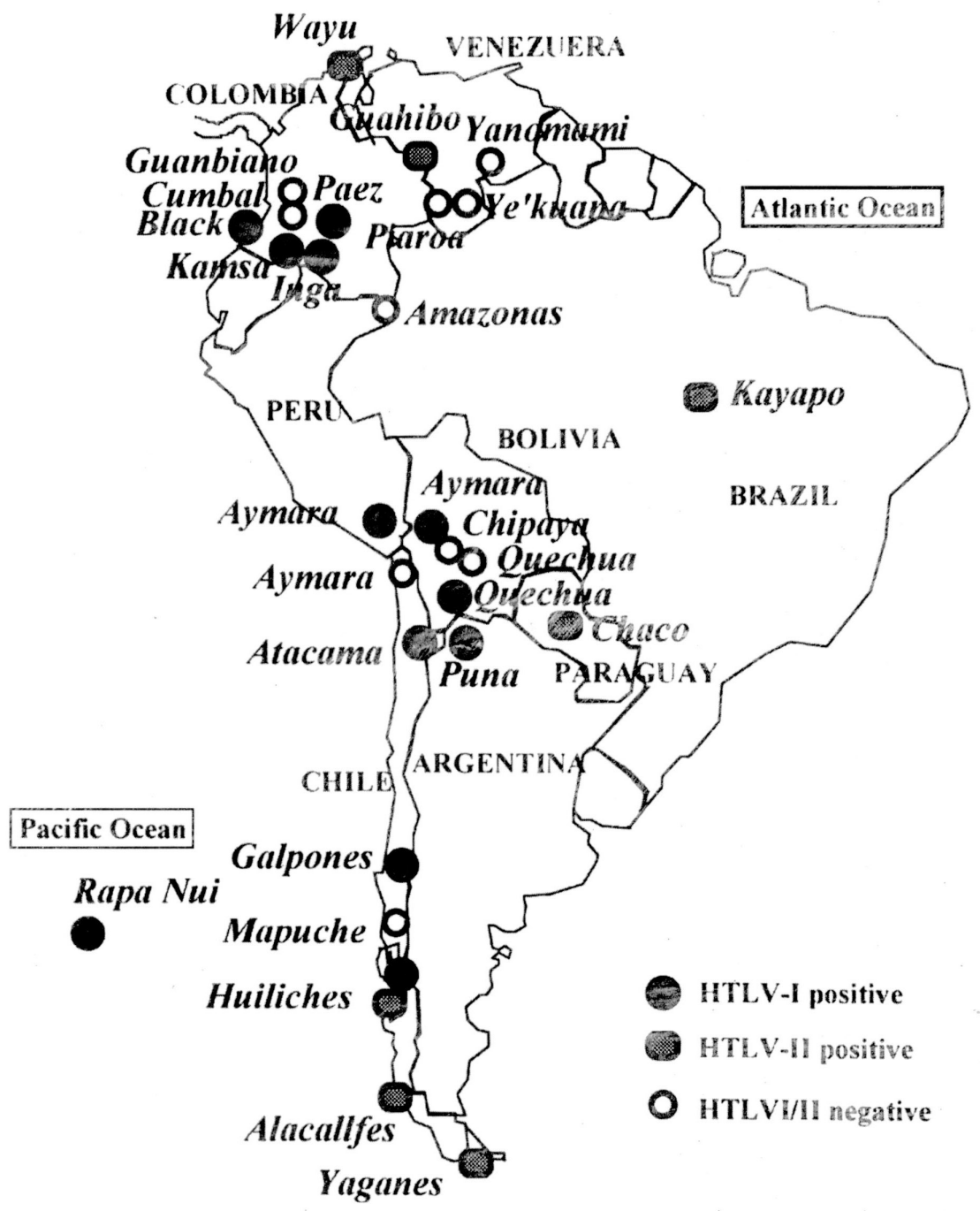

Figure 1. Geographical distribution of HTLV-I and -II foci in South America. Location and names of ethnic groups correspond to the names for ethnicity and locality given in Table 1. 


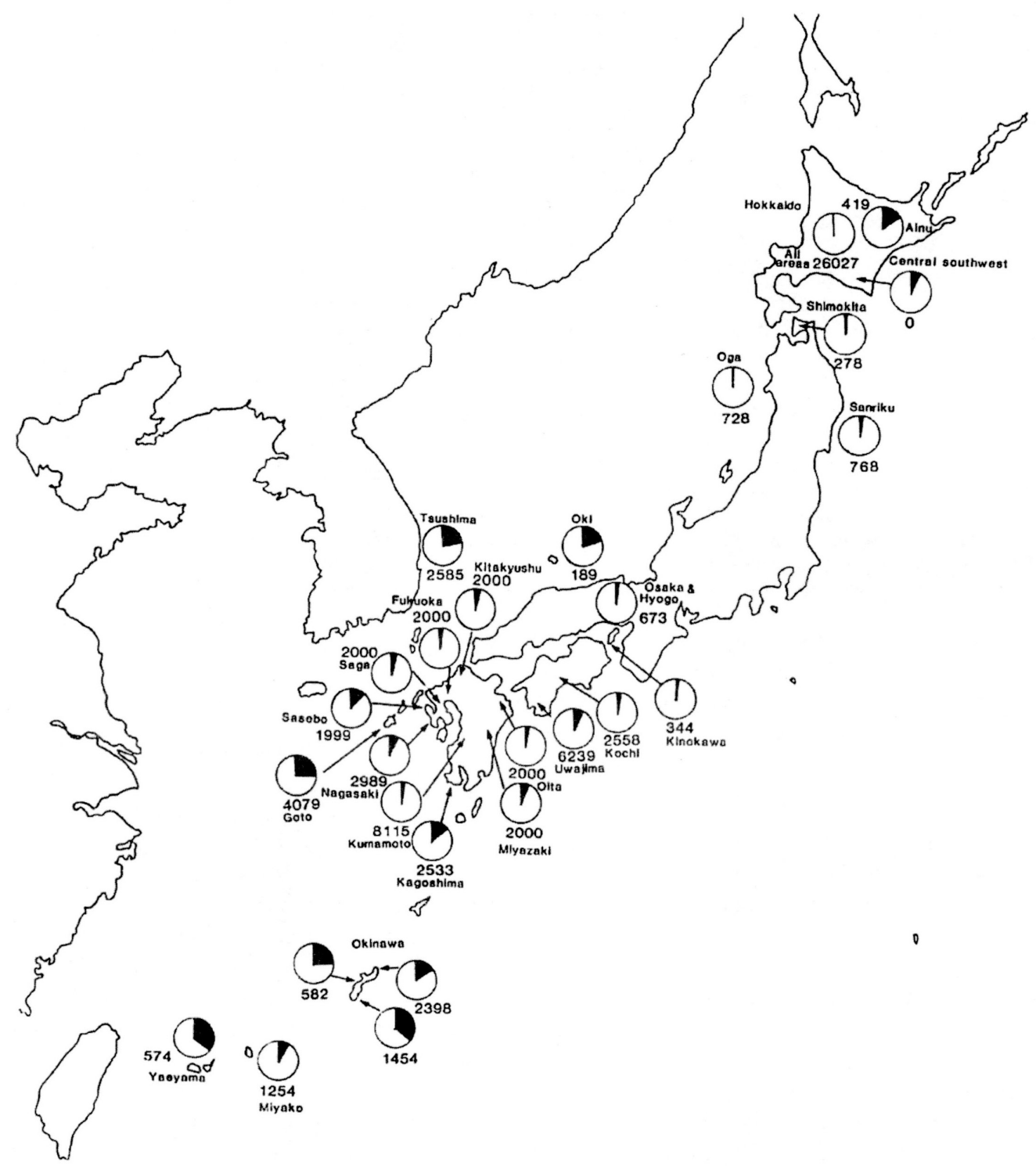

Figure 2. Geographical distribution of positive anti HTLV-I incidence in Japanese people. Location and names correspond to the names for locality given in Table 2. 


\begin{tabular}{|c|c|c|c|c|}
\hline District $^{2}$ & Area & (Subarea, group) & Subjects & Positive rate $(\%)$ \\
\hline \multirow[t]{2}{*}{ Hokkaido } & \multirow[t]{2}{*}{ Central south } & (Hidaka) & 1,434 & 2.6 \\
\hline & & $(\text { Ainu })^{4}$ & 419 & 18.4 \\
\hline \multirow[t]{2}{*}{ Shikoku } & \multirow[t]{2}{*}{ South coast } & (Uwajima) & 6,239 & 7.5 \\
\hline & & (Kochi) & 2,558 & 3.6 \\
\hline \multirow[t]{7}{*}{ Kyushu } & \multirow[t]{3}{*}{ Northwest } & (Saga) & 2,000 & 3.9 \\
\hline & & (Sasebo) & 1,999 & 9.3 \\
\hline & & (Nagasaki) & 2,989 & 6.7 \\
\hline & \multirow[t]{2}{*}{ Northwest island } & (Tsushima) & 2,585 & 22.7 \\
\hline & & (Goto) & 4,079 & 25.9 \\
\hline & Southeast & (Miyazaki) & 2,000 & 7.4 \\
\hline & South & (Kagoshima) & 2,533 & 11.7 \\
\hline \multirow[t]{5}{*}{ Okinawa $^{3}$} & \multirow[t]{3}{*}{ Main island } & (North) & 2,398 & 18.3 \\
\hline & & (Central) & 582 & 24.1 \\
\hline & & (South) & 1,454 & 32.6 \\
\hline & \multirow[t]{2}{*}{ Southern island } & (Miyako) & 1,254 & 5.2 \\
\hline & & (Yaeyama) & 574 & 33.4 \\
\hline
\end{tabular}

1 Anti-HTLV-1 antibodies were confirmed by immunofluorescence testing.

2 Location corresponds to that in Fig. 2.

3 Okinawa prefecture is included in Kyushu district. The main and southern islands are located about $800 \mathrm{~km}$ and $1,200 \mathrm{~km}$ south of Kagoshima, respectively.

4 Blood samples from a native Japanese (Ainu) were collected about 30 years ago (1966-70)

Referenced from Maeda el al, 1984; Tajima and Hinuma, 1992; Ishida el al, 1985

Table 2. Distribution of adult anti-HTLV-I antibody positives ${ }^{1}$ in northern and southern ATL-endemic districts of Japan

rates among women is thought to be the increased transmission risk with cumulative exposure to the virus through repeated sexual contacts.

\section{CONTRASTING HTLV-I RELATED DISEASES}

ATL: The annual incidence rate of ATL in endemic areas of Japan is approximately $1 / 1,000$ in male adult HTLV-I carriers and 1/2,000 in females, older than 40 years old of age (Tajima et al., 1985, Kondo et al., 1989 and Tokudome et al., 1989), not very different from findings in Jamaica (Murphy et al., 1989). However, the age distribution in Jamaica is shifted towards the younger generation, compared with Japanese patients, perhaps the most important factor in this context being of age differences in the life span.

TSP/HAM: HAM/TSP (Osame et al., 1986; Gessain et al., 1985) is the second most common disease caused by HTLV-I infection. Its clinical diagnostic criteria have been established by a WHO working group which identified differences from multiple sclerosis, spinal cord compression, spinal canal stenosis and cervical spondylosis (WHO, 1989). In general, HAM/TSP is a chronic progressive spastic myelopathy with demyelination of the spinal cord motor neurons. The main clinical symptoms are limping due to stiffness of the lower limbs, dysuria because of urinary bladder disfunction, paraesthesias, lumbar pain and impotence (Table 3). Difficulties in walking develop slowly and cerebellar symptoms and cranial nerve palsies are not observed.

Contrasting features: The main immunological features of HAM/TSP are the presence of high titers of anti-HTLV-I antibodies in serum and cerebrospinal fluid, a high proviral load in the peripheral blood cells, and the presence of cytotoxic T-cells which recognize epitopes of the tax gene product (Jacobson et al., 1990). A small number of circulating abnormal flower-like lymphocytes is observed in many patients (Dalgleish et al., 1988), which may cause confusion with the chronic type of ATL. The pathogenesis of HAM/TSP is uncertain, 
but some specific type of human leukocyte antigen (HLA) variability, associated with viral load and the immune response, is considered as a potential factor determining susceptibility to disease development (Sonoda et al., 1996).

International comparison: A previous study showed that most ATL patients have specific HLA haplotypes found only in a minority Japanese subpopulation, while HAM/TSP patients share common HLA haplotypes appearing in the majority of Japanese (Table 3). In Japan the number of cases of ATL exceeds that of HAM/TSP, but HAM/TSP is more prevalent in Chile (Table 4). In both countries, the ratio of males to females is more than 1.2 for ATL patients and less than 0.5 for HAM/ TSP cases. Such a geographical discrepancy between ATL and HAM/TSP might be explained by a different genetic background between Japanese and Chilean carriers of HTLV-I. All Japanese carriers of HTLV-I at risk of HTLV-I related diseases are Mongoloids, whereas recent Chilean carriers are of mixed Mongoloid and Caucasoid stock. Thus present-day Chilean carriers of HTLV-I share a genetic background with Caucasoid people which is very different from that of the original South American Mongoloids.

\section{MONGOLOIDS DISPERSAL TO SOUTH AMERICA}

HTLV-I group: HTLV-I carriers in the Andes highlands were found to be remarkable with respect to ethnic clusters in Inga, Kamsa, Aymara, Quechua, Atacama, and Puna, distributed from south Colombia to southeast Peru, Central-Southwestern Bolivia, northern Chile and northern Argentina. Phylogenetic studies of HTLV-I isolates of Andean ethnic groups have shown that the native Amerindians harbor HTLV-I isolates of the transcontinental subgroup (subtype A), and there is some relation between the Japanese HTLV-I foci and Andes HTLV-I carriers. HTLV-I positive cases in the Hulliches and Rapa Nui were also the some type, despite being remote from the Andes highlands (Miura et al., 1997). It is thus suggested that all South American HTLV-I carriers may have originated in the Andes highlands, genetically derived from a Mongoloid lineage carrying the transcontinental subtype A of HTLV-I provirus DNA.

HTLV-II group: HTLV-II foci were found in the Brazilian Kayapo tribe (57.9\%), Paraguayan Chacos
(16.4\%), Chilean Alacalufes (34.8\%) and Yaganes $(9.1 \%)$, in line with a previous report of natural endemic foci in indigenous South American groups on the Atlantic coast and in the Orinoco lowlands of Colombia (Fujiyama et al., 1993; Zaninovic et al., 1994). Thus there is a clear geographic independence of HTLV-I and HTLV-II, the former mainly infecting Andes ethnic groups, and the latter non- Andean lowland ethnic groups. Furthermore, the incidence rate for HTLV-II carriers is generally higher than that for HTLV-I carriers (Table 1), again suggesting independent isolated populations.

\section{Coexistence of HTLV-I and II groups: However of} interest is the co-existence of HTLV-I and HTLV-II in the Huilliches in Chiloe Island, as well as in the Wayu on the Atlantic coast of Colombia reported earlier (Duenas-Barjas et al., 1992). Although our examination of samples taken from the Wayu revealed only HTLV-II carriers, it is possible that such lowland tribes in coastal areas are a result of the convergence of groups of HTLV-I and HTLV-II carriers.

Hypothetical routes: HTLV-I and HTLV-II foci exhibit geographically and ethnically independent distributions in the Andes highlands and in the Orinoco lowlands of Colombia (Fujiyama et al., 1993; Zaninovic et al., 1994), and a common HLA ha-plotype is associated with HTLV-I carriers in both Andes Indians and Japanese HTLV-I endemic populations, in contrast to the completely independent HLA haplotypes associated in HTLV-II carriers specific to Orinoco lowland and North American Indian groups (Fujiyoshi et al., 1995). Our data for geographical dispersion suggests that HTLV-I and HTLV-II evolved among Mongoloids were transmitted independently to people in the American continent by historical dispersal of ancestral Mongoloids who migrated from Asia.

To explain this unique distribution of HTLV-I, several hypothetical models of migration of HTLV-I and -II carriers can be generated as follows (Fig. 3): 1) both HTLV-I and HTLV-II carrying Asians migrated to the American continent in several waves but only HTLV-I carriers arrived and settled in the Andes areas; 2) after Asian migration, HTLV-II carriers arrived and spread HTLV-II through Pan-American areas other than the Andes; 3) after migration of HTLV-II carrying Asians, HTLV-I carriers newly arrived in the Andes areas through transpacific routs. As Estrada and Meggers first pointed out more than 30 years 


\begin{tabular}{|c|c|c|}
\hline Item compared & Adult T-cell leukemia(ATL) & HTLV-I associated myelopathy (HAM) \\
\hline Disease character & Neoplastic disease & Reactive disease \\
\hline \multirow[t]{3}{*}{ Main symptoms } & Leukemia/lymphoma & Spastic gait \\
\hline & Skin lesion & Dysuria \\
\hline & Hypercalcemia & Sensory disturbance \\
\hline \multirow{3}{*}{$\begin{array}{l}\text { Age distribution } \\
\text { (age mode) } \\
\text { (over } 40 \text { years) }\end{array}$} & Adults over 20 years & Children and adults \\
\hline & (55-65 years) & (35-45 years) \\
\hline & $94 \%$ & Unknown \\
\hline \multirow{4}{*}{$\begin{array}{l}\text { Sex distribution } \\
\text { (sex ratio) } \\
\text { Transmission route } \\
\text { (manifestation) }\end{array}$} & Male $>$ female & Male $<$ female \\
\hline & $(\mathrm{M} / \mathrm{F}=1.2)$ & $(\mathrm{M} / \mathrm{F}=0.5)$ \\
\hline & Vertical (yes) & Vertical (yes) \\
\hline & Horizontal (no or rare) & Horizontal (yes) \\
\hline Latent period & Longer than 20 years & Longer than 6 months \\
\hline $\begin{array}{l}\text { Incidence rate } \\
\qquad \text { (cumulative risk) }\end{array}$ & $\begin{array}{l}0.5-1.5 / \text { year } / 1,000 \\
(2-6 \%)\end{array}$ & $\begin{array}{l}\text { Less than } 0.5 / \text { year } / 1,000 \\
\text { (less than } 1 \% \text { ) }\end{array}$ \\
\hline \multirow{2}{*}{$\begin{array}{l}\text { Immune reactivity } \\
\quad \text { (antibody titer) } \\
\text { Common HLA haplotypes }\end{array}$} & $\begin{array}{l}\text { Normal or diminished } \\
\text { (relatively low) }\end{array}$ & $\begin{array}{l}\text { Elevated } \\
\text { (generally high) }\end{array}$ \\
\hline & & \\
\hline (A,B,C types) & A26Cw3Bw62, etc & A24Cw7B7, AllCw1Bw54, etc. \\
\hline (DRB1-DQB1) & 0901-0303, etc. & 0405-0401, etc. \\
\hline
\end{tabular}

Referenced from Tajima et al, 1995; Sonoda et al, 1996

Table 3. Comparison of clinicoepidemiological, immunological and genetic features between two HTLV-I-associated diseases (ATL and HAM) in Japan

\begin{tabular}{|c|c|c|c|c|}
\hline \multirow[b]{2}{*}{ Comparative item } & \multicolumn{2}{|c|}{ Japan* } & \multicolumn{2}{|c|}{ Chile** } \\
\hline & ATL & HAM & ATL & HAM \\
\hline Periodofregistration & $1988-93$ & $1987-94$ & $1989-92$ & $1987-90$ \\
\hline Number of cases & 2,200 & 1,103 & 8 & 45 \\
\hline Average annual cases reported & 366.7 & 137.9 & - & - \\
\hline Average age al onset (Years) & 58.5 & 45.2 & 51.8 & 47.2 \\
\hline (Range) & $(19-89)$ & $(5-80)$ & $(24-78)$ & $(20-7)$ \\
\hline Sex ratio (Male/Female) & 1.22 & 0.46 & 1.00 & 0.45 \\
\hline
\end{tabular}

* New cases were collected by nation wide registry from hospitals. Referenced from The T- and B-cell Malignancy Study Group, 1996; Osame et al, 1994.

** Reported cases rather than nationwide study from references. Referrenced from Cartier et al, 1992; Cabrera et al, 1994.

Table 4. Comparison of clinico-epidemiological features of ATL and HAM between Japan and Chile. 


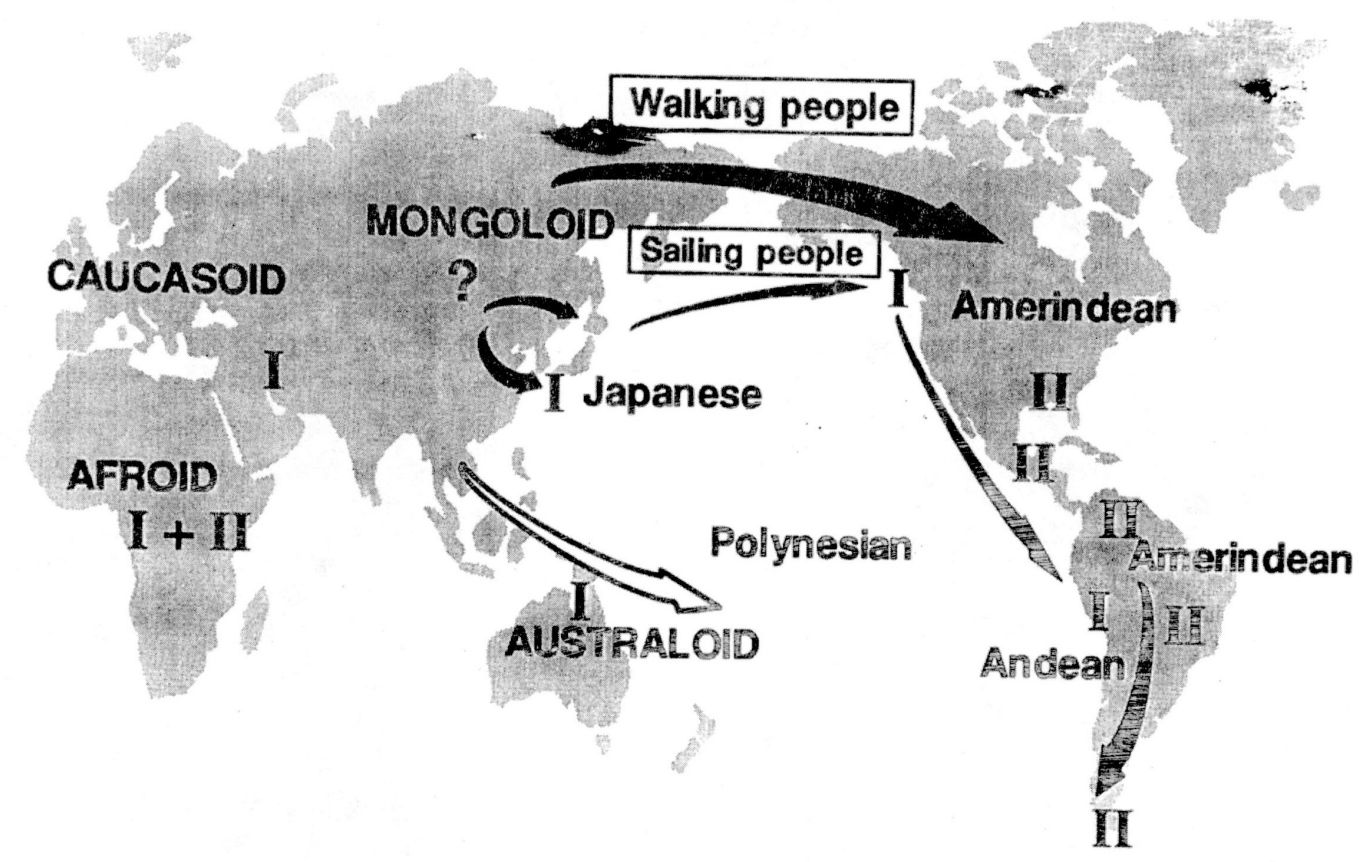

Figure 3. Hypothetical migration routes of Asian mongoloids from Asia to the American Continent.

ago (Estrada et al., 1962), the third hypothesis seems plausible because of similarity of genetic background between southern Japanese and only Andeans in South America. However, it has not been accepted by all anthropologists and archeologists. To clarify the relationship between Asian and Andean HTLV-I carriers, further epidemiological and genetic studies, for example in the northwestern coast of Canada and Tibet, in Asia are indispensable. Comprehensive information on the HTLV-I distribution in Pan Pacific areas may give further hint to the relationship between Japanese and Andean ancestors and the history of their dispersal and settlements in each area.

\section{REFERENCES}

CABRERA M. E., LABRA S., CATOVSKY, D. FORD, A. M. 1994 COLMAN, S. M. GREAVES, M. F. and MATUTES E. HTLV-I positive adult T-cell leukaemia/Iymphoma (ATLL) in Chile Leukemia 8: 1763-1767

CARTIER, A, F., CASTILLO J.L., RUIZ, F., GORMAZ and 1992 TAJIMA, K. Progressive spastic paraparesis associated with human T-cell leukemia virus type I (HTLV-I) Internal Medicine 31 1257-1261.

CARTIER, L., ARAYA, F., CASTILLO, J.L., ZANINOVIC, V., 1993 HAYAMI, M., MIURA, T., IMAI, J., SONODA, S., SHIRAKI, H., MIYA-MOTO, K. and TAJIMA, K. Southernmost carriers of HTLV-I/II in the world. Jpn. J. Cancer Res. 84: 1-3.

DALGLEISH, A., RICHARDSON, J., MATUTES, E., 1988 CRUICKSHANK, K., NEWELL, A.,
SINCLAIR,A., THORPE, R., BRASHER, M., WEBER, J.. CATOVSKY, D. and RUDGE; P. HTLV-I infection in tropical spastic paraparesis: Iymphocyte culture and serological response. Journal of Infectious Diseases 161: 359-360.

DUENAS-BARJAS, E., BERNAL, J. E., VAUGHT, D.R.., 1992 BRICENO, I., DURAN, C., YANAGIHARA, R., GAJDUSEK, C. Coexistence of human T-Iymphotropic virus types 1 and II among the Wayuu Indians from the Guajira region of Colombia. AIDS Res. Hum. Retroviruses 8:1851-5.

ESTradA, E., MEGGERS, B.J., EVANS, C. Possible 1962 transpacific contact on the coast of Ecuador. Science 135: 371-372.

FUJIYAMA, C., FUJIYOSHI, T., MIURA, T., YASHIKI, S., 1993 MATSUMOTO, D., ZANINOVIC, V., 
BLANCO, O., HARRINGTON, W. Jr, BYRNES, J.J., HAYAMI, M., TAJIMA, K. and SONODA, S. A new endemic focus of human $\mathrm{T}$ Iymphotropic virus type II carriers among Orinoco natives in Colombia. J. Infect. Dis. 168: 1075-7.

FUJIYOSHI, T, FUJIYAMA, C., YASHIKI, S., HALL, W.W., 1995 ZANIMOVIC, V., CARTIER, L., HAYAMI, M., TAJIMA, K. and SONODA, S. Nucleotide sequences in the gag p19 gene region of HTLV-II isolates from HTLV-II carriers in South American natives. JAIDS Human Retro-virology. 10: 281.

FUJIYOSHI, T., YASHIKI, S., FUJIYAMA, C., KUWAYAMA, 1995 M., MIYASHITA, H., OHNISHI, H., BLANK, M., ZANINOVIC, V., CARTIER, L., BLANK, A., BYRNES, J.J., HARRINGTON, W.W. Jr, MIURA, T., HAYAMI, M., TAJIMA, K., SONODA, S. Ethnic segregation of HTLV-I and HTLV-II carriers among South American native Indians. Int. J. Cancer 63: 510-5.

GESSAIN, A., BARIN, F., VERNANT, J.C., GOUT, 0., 1985 MAURS, L., CALENDER, A. The G. Antibody to human T-Iymphotropic virus type-I in Patients with tropical spastic paraparesis. Lancet ii: 407-409.

GESSAIN, A., MAUCLERE, P., PROMENT, A., BIGLIONE, 1995 M., HESRAN, J.Y.L., TEKAIA, F., MILLAN, J. The G. Isolation and molecular characterization of a human T-cell lymphotropic virus type II (HTLVII), subtype B, from a healthy Pygmy living in a remote area of Cameroon: An ancient origin for HTLV-II in Africa. Proceedings of the National Academy of Science at the USA 924041-4045.

HINUMA, Y., NAGATA, K., HANAOKA, M., NAKAI, M., 1981 MATSUMOTO, T. KINOSHITA, K., SHIRAKAWA, S. and MIYOSHI, I. Adult T-cell leukemia: Antigen in an An cell line and detection of antibodies to the antigen in human sera. Proceedings of the National Academy of Science at the USA 78: 6476-6480.

IDO, E., YAMASHITA, M. and HAYAMI, M. Ethnic variation 1996 of HTLV in the world. Gann Monograpb on Cancer. Research 44:107-120.

ISHIDA, T., YAMAMOTO, K., OMOTO, K., IWANAGA, M., 1985 OSATO, T. and HINUMA, Y. Prevalence of a human retrovirus in native Japanese: evidence for a possible ancient origin. Journal of Infection 11: 153-157.

JACOBSON, S., SHIDA, H., McFARLIN, D. E., FAUCI, A.S. 1990 and KOENIG, S. Circulating CD8+ cytotoxic $\mathrm{T}$ Iymphocytes specific for HTLV-I pX in palients with HTLV-1 associated neurological disease. Nature 348: 254-248.

KALYANARAMAN, V. S., SARNGADHARAN, M. G., 1982 ROBERT-GUROFF, M., MIYOSHI, I., BLAYNEY, O., GOLDE, O. and GALLO, R.C. A new subtype of human T-cell leukemia virus (HTLV-II) associated with a T-cell variant of hairy cell leukemia. Science 218: 571-573.

KINOSHITA, K., HINO, S., AMAGASAKI, T., IKEDA, S., 1984 YAMADA, Y., SUZUYAMA, J., MOMITA, S., TORIYA, K., KAMIHIRA, 5. and ICHIMARU, M. Demonstration of adult T-cell leukemia virus antigen in milk from three sero-positive mothers. Japanese Journal of Cancer Research 5:103-105.

KORALNIK, I.J., BOERI, E., SAXINGER, W. C., LO 1994 MONICO, A., FULLEN, J., GESSAIN, A., GUO, H-G, GALLO, R.C., MARKHAM, P., KALYANARAMAN, V., HIRSCH, V., ALLAN, J., MURPHY, K., ALFORD, P., SLATTERY, J.P., O'BRIEN, S.J. and FRANCHINI, G. Phylogenetic associations of human and simian T-cell leukemia/lymphoma virus type I strains: evidence for interspecies transmission. Journal of Virology 68: 2693-2707.

KUSUHARA, K., SONODA, S., TAKAHASHI, S., 1987 TOKUGAWA, K:, FUKUSHIMA, J.and UEDA, K. Mother-to-child transmission of human T-cell leukemia virus type I (HTLV-I): A fifteen-year follow-up in Okinawa. Japan International Journal of Cancer 40: 755-757.

MEYTES, D., SCHOCHAT, B., LEE, H., NADEL, G., SIDI, Y., 1990 CERNEY, M., SWANSON, P., SHAKLAI, M., KILIM, Y., ELGAT, M., GHIN, E., DANON, Y. and ROSENBLATT, J.D. Serological and molecular survey for HTLV-I infection in a high-risk Middle Eastern group. Lancet 336: 1533-1535.

MIURA, T., YAMASHITA, M., VLADIMIR, Z., CARTIER, 1997 L., TAKEHISA, J., IGARASH, T., IDO, E., FOJIYOSHI, T., SONODA, S., TAJIMA, K. HAYAMI, M. Molecular phylogeny of human T-cell leukemia virus type I and II of Amerindians in Colombia and Chile. J. Mol. Evol. 44: S76-82.

NAKANO, S., ANDO, Y., ICHIRO M., MORIYAMA, L., 1984 SAITO, S., SUGIMURA, K. and HINUMA, Y. Search for possible routes of vertical and horizontal transmission of adult T-cell leukemia virus. Japanese Journal of Cancer Research 75: 10441045.

OSAME, M., NAKAGAWA, M., KUBOTA, H. and

1994 TAKAMORI, M. The second nationwide survey of HTLV-1-associated myelopathy (HAM) in Japan Annual Report in 1994 on Neuroimmunological Research Committee of the Ministry of Health and Welfare of Japan 11-13 (in Japanese).

OSAME, M., USUKU, K.. IZUMO, S., IJICHI, N., AMITANI, 1986 H., IGATA, A., MATSUMOTO, M. and TARA, M. HTLV-I-associated myelopathy, A new clinical entity. Lancet is 1031-1032.

POIESZ, B.J., RUSCETTI, F.W., GAZDAR, A.F, BUNN, P.A., 1980 MINNA, J.D, and GALLO, R.C. Detection 
and isolation of type-C retrovirus particles from fresh and cultured lymphocytes of patients with cutaneous T-cell lymphoma. Proceedings of the National Academy of Science of the USA 77: 7415-7419.

SONODA, S. and FUJIYOSHI, T. HTLV-I infection and HLA 1996 Gann. Monograph on Cancer Research 44: 207-217.

TAJIMA, K. HTLV-UII related diseases with special 1996 reference to its distribution among Mongoloids Gann. Monograph on Cancer Research 44: 207-217.

TAJIMA, K. and HINUMA, Y. Epidemiology of HTLV-1/I1 in 1992 Japan and the world GANN. Monograph of Cancer Research 39: 129-149.

TAJIMA, K., KAMURA, S., ITO, S., ITO, M., NAGATOMO, 1987 M., KINOSHITA, K. and IKEDA, S. Epidemiological features of HTLV1 carriers and incidence of ATL in an ATL-endemic island: A report of the community-based cooperative study in Tsushima. Japan International Journal of Cancer 40: 741-746.

TAJIMA, K. The T- and b-cell,Malignancy Study Group 1990 and Co-authors. The 4th nation-wide study of adult T-cell leukemia/lymphoma (ATL) in Japan: Estimates of risk of ATL and its geographical and clinical features. International Journal of Cancer 45: 237243.

TAKEZAKI, T., TAJIMA, K., ITO, M., ITO, S., KINOSHITA, 1997 I., TACHIBANA, K., MATSUSHITA, Y. The Tsushima ATL Study Group. Shortterm breast-feeding may reduce the risk of vertical transmission of HTLV-1.
Leukemia 11:60-61.

1988

The T- and B-cell Malignancy Study Group. The third nation wide study on adult T-cell leukemia/lymphoma (ATL) in Japan: Characteristic patterns of HLA antigen and HTLV-I infection in ATE, patients and their relatives. International Journal of Cancer 41: 505-512.

The T- and B-cell Malignancy Study

1998 Group. A report from the 8th nationwide study of adult T-cell leukemia/lymphoma (ATL in Japan). Japanese Journal of Cancer Clinics 44: 381-397 (in Japanese).

UCHIYAMA, T., YODOI, J., SAGAWA, K., TAKATSUKI, K. 1977 and UCHINO, H. Adult T-cell leukemia: Clinical and hematologic features of 16 cases. Blood 50: 481-492.

ZANINOVIC, V., SANZON, F., LOPEZ, E, VELANDIA, G., 1994 BLANK, A., BLANK, M., FUJIYAMA, C., YASHIKI. S., MATSUMOTO, D., KATAHIRA, Y., MIYASHITA, H., FUJIYOSHI, T., CHAN, L., SAWADA, T., MIURA, T., HAYAMI, M., TAJIMA, $\mathrm{K}$. and SONODA, S. Geographic independence of HTLV-1 and HTLV-II foci in the Andes Highland. the Atlantic Coast, and the Orinoco of Colombia AIDS. Research \& Human Retroviruses 10: 97-101.

Acknowledgments: This study was supported by Grants from the Ministry of Education. Science, Sports and Culture of Japan, The Ministry of Health and Welfare of Japan, The Mitsubishi Foundation and The Kodama Memorial Fund for MedicalResearch. and ThePrincess Takamatsu Cancer Research Fund. 
